\title{
BALANCING UNQUANTIFIED HARMS AND BENEFITS IN ANTITRUST CASES UNDER THE CONSUMER WELFARE STANDARD
}

\author{
The Hon. Douglas H. Ginsburg*
}

William Howard Taft-the most under-appreciated constitutional figure since George Mason, the father of the Bill of Rights-is no doubt best known as the 27th President, but his most significant contributions to our constitutional order came as Chief Justice. The federal judiciary today is the federal judiciary Taft gave us. During his tenure as Chief Justice, Taft convinced the Congress to create the Judicial Conference as the governing body of the federal courts; give the Supreme Court its own building; and, in the Judiciary Act of 1925, eliminate most of the Supreme Court's mandatory jurisdiction. ${ }^{1}$ These reforms bolstered the independence of the federal judiciary, and permanently elevated its role in our society.

Taft also made important contributions to antitrust, both as a judge $e^{2}$ and during his time as president. Although his predecessor, Teddy Roosevelt, is remembered as the "trustbuster," Taft's administration brought nearly twice as many cases in half the time. ${ }^{3}$ As Jeff Rosen explains in his excellent brief biography of Taft, TR and his successor had diametrically opposed ideas about how best to assure the competitiveness of markets. ${ }^{4}$ Roosevelt championed a

* Circuit Judge, U.S. Court of Appeals for the District of Columbia Circuit. A version of this Article was delivered as the William Howard Taft Lecture, September 27, 2019, to the New York State Bar Association, Antitrust Law Section. I gratefully acknowledge research assistance of Jake Philipoom and Cerin Lindgrensavage.

1 JefFrey Rosen, William Howard TAFT 114 (Arthur M. Schlesinger, Jr. \& Sean Wilentz eds., 2018).

2 See, e.g., United States v. Addyston Pipe \& Steel Co., 85 F. 271 (6th Cir. 1898).

3 Rosen, supra note 1 , at 86.

4 Rosen, supra note 1 , at 44, 85-86. 
regulatory model, with strict federal oversight of large corporations. ${ }^{5}$ Taft favored a law enforcement model, with aggressive prosecution of anticompetitive conduct, bearing in mind that "[m]ere size is no sin against the law." In my view, Taft's approach was preferable and has been vindicated over the course of the last century. The regulatory model would have substituted the discretion of regulators for the decisions of risk takers, with distortionary and welfare-reducing effects. The law enforcement approach, by contrast, protects competition while adhering to the rule of law. ${ }^{7}$ In this Article I hope to continue in Taft's reformist footsteps by suggesting some additional tools antitrust enforcers and courts can use to make coherent, evidence-based decisions in the face of measurement difficulties.

I. Introduction .825

II. How Antitrust Agencies and Courts Have Handled Balancing

A. Merger Cases .................................................829

B. Horizontal Restraints ....................................... 832

C. Non-competition Justifications ..........................834

III. Administrative Agency Rulemaking Can Inform the Balancing of Unquantified Harms or Benefits..........837

A. Executive Review..........................................839

B. Judicial Review........................................... 842

IV. Proposal to Help Inform Balancing of Unquantified Harms and Benefits

\section{INTRODUCTION}

As then-Judge Taft recognized back in 1898, a restraint of trade should be condemned only if it reduces competition and hence consumer welfare; and we all know from cases such as

5 Rosen, supra note 1 , at 85.

6 Rosen, supra note 1 , at 86.

7 See Joshua D. Wright \& Douglas H. Ginsburg, The Economic Analysis of Antitrust Consents, 46 EU. J.L. ECON. 245, 246-47 (2018). 
Chicago Board of Trade v. United States, ${ }^{8}$ an arrangement may both restrain and facilitate trade and, on balance, be procompetitive. ${ }^{9}$ This seems obvious enough in principle, but in practice how are agencies and courts to assess the balance between the restraint or facilitation of trade or, put another way, the balance between the harms and benefits? I believe that certain tools used by agencies that do cost-benefit analyses before issuing regulations could help antitrust agencies make the required assessments. ${ }^{10}$

In the last few years, some have questioned the propriety of the consumer welfare standard. There have been calls for antitrust enforcers and courts to consider all manner of other criteria in addition to the welfare of consumers. ${ }^{11}$ Doing so would require making complex tradeoffs among incommensurable goals, without any principled way to do so. ${ }^{12}$ The effect would be to place unbridled and unreviewable discretion in the hands of enforcers and courts, inviting arbitrary decisions and creating uncertainty for firms. ${ }^{13}$ Accepting nebulous theories of harm (such as the

8 Chi. Bd. of Trade v. United States, 246 U.S. 231 (1918).

9 See United States v. Addyston Pipe \& Steel Co., 85 F. 271, 280-81 (6th Cir. 1898).

10 See Rebecca Haw Allensworth, The Commensurability Myth in Antitrust, 69 VAND. L. REV. 1, 63-65 (2016) (discussing the need for more rigorous cost-benefit analysis in antitrust cases).

11 See, e.g., K. Sabeel Rahman \& Lina Khan, Restoring Competition in the U.S. Economy, in UnTAMEd: How to CHEck Corporate, Financial, AND MONOPOly Power 18, 23 (Nell Abernathy et al. eds., 2016) (calling for a new antitrust statute defining a "citizen interest" or "public interest" standard); Maurice E. Stucke, Reconsidering Antitrust's Goals, 53 B.C. L. REV. 551, 600-02 (2012) (arguing that competition policy should balance consumer welfare against "quality of life factors," which may include "health status, work and life balance, education and skills, social connections, civic engagement and governance, environmental quality, personal security, and subjective well-being").

12 See Douglas H. Ginsburg et al., The FTC's Hearings on Competition and Consumer Protection in the 21st Century, The Consumer Welfare Standard in Antitrust Law (George Mason Univ. Law \& Econ. Research Paper Series, No. 18-26, 2018), https://ssrn.com/abstract=3245912 [https://perma.cc/HY3J-P7VJ].

13 See id. at $5-6$. 
"accumulation of political power"), ${ }^{14}$ and by parity of reasoning, vague "public interest" defenses (such as a claim that an agreement among rivals would reduce economic inequality) would lead to inconsistent results and evade the rule of law. This is not to deny that even under the consumer welfare standard, difficult tradeoffs sometimes have to be made, but they all involve palpable harms or benefits, not subjective political preferences.

Although some critics charge that antitrust under the consumer welfare standard revolves solely around price effects ${ }^{15}$ this is simply not the case. Other dimensions of competition also affect consumer welfare, including product quality, service, and innovation. Antitrust enforcement under the consumer welfare standard routinely takes these factors into account whenever they are likely to be significant. ${ }^{16}$ Nonprice considerations surely affect consumer welfare, ${ }^{17}$ and in some instances may be more significant than price effects. Admittedly, cases with non-price effects present a greater challenge for enforcers and courts because the non-price effects can be difficult or impossible to quantify. The temptation to ignore the qualitative must be resisted, however. ${ }^{18}$

14 See Marshall Steinbaum \& Maurice E. Stucke, A New Standard for Antitrust: The Effective Competition Standard: In Practice, RoosevelT InstiT., Sept. 2018, at 8, https://rooseveltinstitute.org/wpcontent/uploads/2018/09/Effective-Competition-Standard-issue-briefFINAL.pdf [https://perma.cc/6LU3-4YSU].

15 See, e.g., id. at 1 ("With [the consumer welfare standard's] pricecentric tools, the U.S. competition agencies often cannot assess how mergers and restraints will impact ... quality, privacy, and innovation").

16 See Joshua D. Wright et al., Requiem for a Paradox: The Dubious Rise and Inevitable Fall of Hipster Antitrust, 51 ARIZ. ST. L.J. 293, 357-61 (2019) (discussing examples); Joshua D. Wright \& Douglas H. Ginsburg, The Goals of Antitrust: Welfare Trumps Choice, 81 FoRDHAM L. REV. 2405, 2410 (2013) (noting "[q]uality-adjusted prices "have been part of the industrial organization toolkit since the early 1900s"); see also infra Part II.

17 Cf. Douglas H. Ginsburg, Nonprice Competition, 38 AnTITRust Bull. 83 (1993) (explaining how nonprice competition can serve as a barrier to collusion).

18 See Robert H. Bork, The Antitrust Paradox 127 (1978) ("Economists, like other people, will measure what is susceptible of 
In this Article, I suggest that antitrust enforcers and courts draw upon the tools used by regulatory agencies and reviewed by courts in administrative law cases to assess the balance between claimed harms and benefits when one or more of those harms or benefits are difficult to quantify. Consider, for example, County of Tuolumne $v$. Sonora Community Hospital. ${ }^{19}$ There, a hospital's privileging criteria for caesarian sections had the effect of foreclosing family doctors from $100 \%$ of the relevant market. ${ }^{20}$ The court concluded that this effect was outweighed by the hospital's need to impose minimum standards for providers of C-sections in order to ensure patients' safety. ${ }^{21}$ As this case illustrates, the consumer welfare standard can require an agency or court to make difficult judgments about the magnitude of incommensurate harms (here, diminished consumer health and safety) and benefits (viz., the price and non-price benefits of competition). But the court did not even try to quantify the costs or the benefits; its decision was intuitive and seems conclusory. ${ }^{22}$ A sound theoretical framework is needed to ensure that the harms and benefits are quantified where possible, and even when one side of the ledger cannot be quantified, the balancing of quantified harms against qualitative benefits, or vice-versa, is conducted in a manner more certain to maximize consumer welfare.

measurement and will tend to forget what is not, though what is forgotten may be far more important than what is measured."); S. O'Mahony, Medicine and the McNamara Fallacy, 47 J. RoYAL C. PHYsicians EdinBurGH 281, 281-82 (2017) (discussing the danger of dismissing that which cannot be quantified).

19 County of Tuolumne v. Sonora Cmty. Hosp., 236 F.3d 1148 (9th Cir. 2001).

20 Id. at 1159.

21 Id. at 1160.

22 Id. ("We must balance the harms and benefits of the privileging criteria to determine whether they are reasonable. In this case, any anticompetitive harm is offset by the procompetitive effects of [the hospital's] effort to maintain the quality of patient care that it provides."). 


\section{HOW ANTITRUST AGENCIES AND COURTS HAVE HANDLED BALANCING}

Both the structure of the balancing inquiry and courts' receptivity to qualitative justifications depend upon the specifics of the case. Generally, courts are willing to entertain qualitative justifications so long as they are based in consumer welfare, although courts are unlikely to bless an otherwise unlawful merger based upon unquantified efficiencies.

\section{A. Merger Cases}

In merger cases where there is likely to be a harm to competition, courts are reluctant to credit offsetting benefits, especially if those benefits cannot be quantified. ${ }^{23}$ In FTC $v$. H.J. Heinz Co., for example, the court approved the FTC's request for a preliminary injunction against a merger between the second and third largest producers of baby food. ${ }^{24}$ The companies had argued that any anticompetitive effects would be overcome by production cost savings, which would be passed on to consumers, and by increased incentives to innovate and to introduce new products. ${ }^{25}$ The court found both arguments speculative: The parties made no effort to estimate the magnitude of their projected cost savings, and offered no data or theory to show the claimed gains to innovation would materialize. ${ }^{26}$

When deciding whether to challenge a merger, agencies are somewhat more receptive than are courts to claims of offsetting efficiencies. ${ }^{27}$ They sometimes accept even hard-to-

23 See, e.g., Saint Alphonsus Med. Ctr.-Nampa Inc. v. St. Luke's Health Sys., Ltd., 778 F.3d 775, 791-92 (9th Cir. 2015) (questioning viability of the efficiencies defense). But see FTC v. Tenet Health Care Corp., 186 F.3d 1045, 1054-55 (8th Cir. 1999) (accepting argument that merger would improve quality of medical care).

24 FTC v. H.J. Heinz Co., 246 F.3d 708, 727 (D.C. Cir. 2001).

25 Id. at $720-24$.

26 Id.

27 See U.S. DeP'T. of Justice \& Fed. Trade Comm'n, Horizontal MERGER GuideLines $§ 10$ (2010). 
quantify efficiencies, such as gains to innovation from combining complementary research and development resources, especially if the potential harm to competition seems slight and the efficiencies, if realized, are likely to be large. ${ }^{28}$

The agencies may also consider hard-to-quantify harms, including harms to innovation that a merger might cause. Both the Antitrust Division of the Department of Justice (the "DoJ") and the FTC have confronted this problem, but the FTC has brought more enforcement actions focused upon innovation as a key factor, no doubt because regulations affecting drugs and devices make it easier to identify potential overlaps in research and development. ${ }^{29}$

Still, the DoJ has scrutinized some mergers based in part upon their potential harm to innovation. ${ }^{30}$ For example, the DoJ alleged harms to innovation in its complaint against the merger of the Dow Chemical Company and E.I. du Pont de Nemours and Company. ${ }^{31}$ The DoJ made those allegations,

28 See Statement of Chairman Timothy J. Muris, In re Genzyme Corp./Novazyme Pharm., Inc., Fed. Trade Comm'n (2004), https://www.ftc.gov/system/files/attachments/press-releases/ftc-closes-itsinvestigation-genzyme-corporations-2001-acquisition-novazymepharmaceuticals-inc./murisgenzymestmt.pdf [https://perma.cc/BH33WJQG]; Press Release, Fed. Commc'ns Comm'n,, Chairman Pai Formally Recommends Approval of T-Mobile/Sprint Merger (Aug. 14, 2019), https://docs.fcc.gov/public/attachments/DOC-359080A1.pdf [https://perma.cc/8SZT-2MAD] (recommending merger in part due to potential to advance implementation of $5 \mathrm{G}$ wireless technology); William J. Kolasky \& Andrew R. Dick, The Merger Guidelines and the Integration of Efficiencies into Antitrust Review of Horizontal Mergers, 71 ANTITRUST L.J. 207, 223 (2003) (discussing author's experience convincing FTC not to challenge a merger of two companies with high market shares in part due to knowledge complementarities).

29 See Ronald W. Davis, Innovation Markets and Merger Enforcement: Current Practice in Perspective, 71 ANTITRUst L.J. 677, 690-93 (2003) (observing that "the FDA's cooperation provides the FTC with extensive information on the status, approach, and likely effect of each innovation effort ... that might have been difficult to obtain otherwise.")(internal quotation marks omitted).

30 See id. at $687-90$.

31 See Complaint at 19, United States v. Dow Chem. Co. et al., 2017 WL 7118163 (D.D.C. 2017) (No. 17-cv-01176-APM). 
however, without quantifying the effect of lost innovation upon competition or consumers. ${ }^{32}$ Estimating the harm from reduced innovation would have shown the importance of innovation in the agency's decision relative to other potential harms, such as the risks associated with increased concentration in those markets in which the parties competed. ${ }^{33}$

Merger cases rarely make it to trial, ${ }^{34}$ so the antitrust agencies have considerable flexibility to consider unquantified harms to innovation without the need rigorously to demonstrate them to the satisfaction of a court. For example, when pharmaceutical companies Genentech, Inc. and Roche proposed to merge, the FTC required divestitures in part due to concerns about the potential harm to innovation, ${ }^{35}$ although the agency did not quantify the potential harm. Had it done so, the present value of that harm presumably would have been discounted because, by the FTC's own reckoning, the companies would not have been competing against each other in some of the relevant markets for several years. ${ }^{36}$

It is unclear whether courts would be as skeptical about an agency's claim that a merger would harm innovation as they seem to be about firms' claims that their merger would spur innovation. Quantifying the alleged harms to innovation could help an agency both in deciding whether to oppose a merger and in supporting its allegations in court. In pharmaceutical mergers, for example, the agency would be more credible if it discounted the potential harm from overlaps in drug

32 See id. at 11-12, 16-17.

33 See Competitive Impact Statement of Plaintiff at 10, 15, United States v. Dow Chem. Co. et al., 2017 WL 7118163 (D.D.C 2017) (No. 17-cv01176-APM) (estimating The Dow Chemical Company and E.I. du Pont de Nemours and Company together accounted for nearly $75 \%$ of the market for chewing pest insecticides and over $99 \%$ of the market for acid copolymers in the United States).

34 Fed. Trade Comm'N \& Dep'T of Justice, Hart-Scott-Rodino Ann. REP. 1-4 (2018).

35 See Roche Holding Ltd., 113 F.T.C. 1086, 1088-89 (1990).

36 See id. at 1108 (dissenting statement). 
development by the estimated probability that both drugs would ever make it to market. ${ }^{37}$

\section{B. Horizontal Restraints}

Courts are more receptive to qualitative justifications for horizontal restraints than they are to qualitative justifications for otherwise harmful mergers. Often the accepted justifications are clearly tied to consumer welfare, even when the benefits to consumers cannot be measured in dollars. ${ }^{38}$ For example, in California Dental Ass'n v. FTC, the Ninth Circuit, on remand from the Supreme Court, had to apply the rule of reason to advertising restrictions that limited the claims dentists could make about the price or quality of their services. ${ }^{39}$ The court first concluded the restrictions had an anticompetitive effect because they suppressed truthful advertising. ${ }^{40}$ The Dental Association then argued the restrictions were procompetitive and necessary to correct information asymmetries and avoid misleading consumers. Neither side tried to quantify the effects it instanced. ${ }^{41}$ Because the procompetitive justifications for the restrictions were supported by expert testimony by both economists and dentists regarding the California dental market, while the alleged anticompetitive effects were supported primarily by a study of advertising restrictions in the legal services market, the court held the FTC had not met its burden of showing a net anticompetitive effect. ${ }^{42}$

37 See Ilene Knable Gotts \& Richard T. Rapp, Antitrust Treatment of Mergers Involving Future Goods, AnTITRUst, Fall 2004, at 100, 101. https://www.nera.com/content/dam/nera/publications/2004/Antitrust_Maga zine_Fall_2004.pdf [https://perma.cc/82XD-RSQE] (arguing that antitrust enforcers should be wary of forecasting harm in markets for goods that do not yet exist, as the FTC did in Genentech).

38 See e.g., NCAA v. Bd. of Regents of the Univ. of Okla., 468 U.S. 85, 103, 117 (1984); Broad. Music, Inc. v. CBS, Inc., 441 U.S. 1, 21-22 (1979); Cal. Dental Ass'n v. FTC, 224 F.3d 942, 952-53 (9th Cir. 2000).

39224 F.3d at $943-45,947$.

40 Id. at 949.

41 See id. at $957-58$.

42 Id. 
Sports leagues provide many examples of courts weighing qualitative arguments in favor of potentially anticompetitive restraints. Courts routinely accept the maintenance of a "competitive balance" among teams as a justification for league rules, ${ }^{43}$ although the incremental contribution of any particular rule to competitive balance, and the resulting contribution to consumer welfare, may be nearly impossible to quantify. ${ }^{44}$ The courts are on solid ground, however; it is intuitively obvious that maintaining a healthy balance among teams improves the quality of league competition by making games closer and season outcomes less predictable, which makes the competition more attractive to fans. ${ }^{45}$ In NCAA $v$. Board of Regents of the University of Oklahoma, where the Supreme Court first accepted competitive balance as a cognizable benefit to consumers, the Court explained that league rules are often justifiable as output-increasing horizontal restraints, much like the restraint it had seen in Broadcast Music, Inc. v. Columbia Broadcasting System, Inc. ${ }^{46}$ More controversially, at least one court has also accepted certain NCAA rules prohibiting compensation as necessary to maintain the member schools' tradition of amateurism, which it deemed output enhancing (by increasing the appeal of collegiate sports to consumers) ${ }^{47}$

43 See, e.g., Major League Baseball Props., Inc. v. Salvino, Inc., 542 F.3d 290, 328 (2d Cir. 2008).

44 See Andrew S. Zimbalist, Competitive Balance in Sports Leagues: An Introduction, 3 J. SPORTS ECON. 111, 119-20 (2002) ("The complexity of factors affecting competitive balance is daunting.").

45 See Smith v. Pro Football, Inc., 593 F.2d 1173, 1175-76 (D.C. Cir. 1978); Peter Kreher, Antitrust Theory, College Sports, and Interleague Rulemaking: A New Critique of the NCAA's Amateurism Rules, 6 VA. SPORTS \& ENT. L.J. 51, 58-59 (2006); Gary R. Roberts, Sports Leagues and the Sherman Act: The Use and Abuse of Section 1 to Regulate Restraints on Intraleague Rivalry, 32 UCLA L. REV. 219, 272 n.180 (1984).

46 NCAA v. Bd. of Regents of the Univ. of Okla., 468 U.S. 85, 103, 117 (1984) (citing Broad. Music, Inc. v. CBS, Inc., 441 U.S. 1 (1979)).

47 See O’Bannon v. NCAA, 802 F.3d 1049, 1073 (9th Cir. 2015) ("[T]he NCAA's compensation rules serve the two procompetitive purposes identified by the district court: integrating academics with athletics, and 'preserving the popularity of the NCAA's product by promoting its current understanding of amateurism."') (quoting O’Bannon v. NCAA, 7 F. Supp. 3d 


\section{Non-competition Justifications}

Only one U.S. court has been receptive to an unquantified justification that had nothing to do with competition. In United States v. Brown University, the Third Circuit reversed a district court's "quick look" review of an agreement among the Massachusetts Institute of Technology and the Ivy League schools not to award merit scholarships and to offer each student admitted to more than one school the same amount of need-based financial aid. ${ }^{48}$ Among the schools' justifications was the claim that their agreement promoted "the social ideal of equality of educational access and opportunity"; by not awarding merit aid, the schools were able to support more students who were otherwise financially unable to attend..$^{49} \mathrm{In}$ the district court's view, promotion of equality was a noneconomic benefit of the agreement, which it could not properly consider. ${ }^{50}$ The Third Circuit, however, held that this noneconomic justification had to be evaluated as part of a full rule of reason analysis. ${ }^{51}$ After the appeal, the parties settled, but then the Congress granted the schools an exemption from the antitrust laws to coordinate financial aid awards. ${ }^{52}$ Despite its ratification by the Congress, the Brown University case is an outlier in U.S. antitrust law, which generally does not accept a justification for restraining trade that is untethered to consumer welfare. ${ }^{53}$

955, 1005 (N.D. Cal. 2014)). See also In re NCAA Athletic Grant-in-Aid Cap Antitrust Litig., 375 F. Supp. 3d 1058, 1083 (N.D. Cal. 2019) (accepting that some limits on student-athlete compensation could be procompetitive, but striking down the compensation limits at issue).

48 United States v. Brown Univ., 5 F.3d 658, 661-63 (3d. Cir. 1993).

49 Id. at 674-75.

50 United States v. Brown Univ., 805 F. Supp. 288, 305 (E.D. Pa. 1992), rev'd, 5 F.3d 658 (3d Cir. 1993).

515 F.3d at 678.

52 Improving America's Schools Act of 1994, Pub. L. No. 103-382, § 568(a)-(d), 108 Stat. 3518, 4060-61 (codified as amended at 15 U.S.C. $§ 1$ (2012)).

53 See, e.g., Nat'l Soc'y of Prof'l Eng'rs v. United States, 435 U.S. 679, 695 (1978) (rejecting a non-competition justification for a horizontal restraint as "a frontal assault on the basic policy of the Sherman Act"). 
The practice of accepting justifications untethered to consumer welfare is somewhat more prevalent overseas, in developed $^{54}$ and particularly in developing countries. The competition law of South Africa, for example, mandates consideration of several non-competition factors, such as employment and opportunities for local businesses. ${ }^{55}$ The South African Competition Tribunal conditioned the merger of Walmart and local retailer Massmart upon the merged firm investing in the development of small and medium-sized local suppliers and training local suppliers to do business with it. ${ }^{56}$

European competition authorities may, though rarely do, consider non-competition justifications under the exemption criteria in Article 101(3) of the Treaty. ${ }^{57}$ The prohibitions of Article 101 "may . . . be declared inapplicable" to agreements and concerted practices that (1) improve the production or distribution of goods, or promote technical or economic progress, provided (2) consumers receive a fair share of the benefit, and (3) the restrictions are indispensable to attainment of the benefits and (4) do not eliminate competition with respect to a substantial part of the relevant market. 58

54 See, e.g., Roger D. Blair \& D. Daniel Sokol, Welfare Standards in U.S. and E.U. Antitrust Enforcement, 81 ForDHAM L. REV. 2497, 2512 (2013) (explaining that E.U. competition law has multiple goals, including "concern for competitors ... and the functioning of the internal market"); NeTHERlands AUTH. FOR CONSUMERS \& MKTS., Vision Document: COMPETITION \& SUSTAINABILITY 3 (2014), https://www.acm.nl/en/publications/publication/13077/Vision-document-onCompetition-and-Sustainability [https://perma.cc/8L3G-9JQY] (clarifying that Dutch competition rules offer room for cooperation with regard to environmental sustainability).

55 Competition Act 89 of $1998 \S 2$ (S. Afr.) (listing purposes to include promotion of employment and social welfare, expanding opportunities for South African participation in world markets, and increasing ownership stakes for historically disadvantaged persons).

56 SA Competition Commission Working Paper CC2016/03 An Ex-Post Review of the Wal-Mart/Massmart Merger (Nov. 2016) (S. Afr.).

57 Treaty on the Functioning of the European Union art. 101, May 9, 2008, 2008 O.J. (C 115) 88-89.

58 Id. 
In one case, the European Commission approved an agreement among "virtually all" manufacturers of washing machines to stop producing and importing the least energyefficient models. ${ }^{59}$ The Commission was able to quantify a likely increase in production costs, which it acknowledged would lead to price increases. ${ }^{60}$ Although it recognized the agreement would restrict competition, the Commission held it met the conditions for an exemption because, among other reasons, it was likely to reduce electricity consumption to the point that consumers would be able to recoup the increased price within a reasonable time. ${ }^{61}$ The Commission also considered the benefits of reduced carbon emissions, which it estimated would be seven times larger than the competitive harm. ${ }^{62}$

Under any rigorous application of the consumer welfare standard, it is logically necessary to consider hard-to-quantify aspects of competition, but that is no reason for a competition agency to weigh "public interest" considerations untethered to competition and consumer welfare. It is also logically necessary to consider the second order or ripple effects of a restraint or merger upon the welfare of all consumers, whether in the market at issue or in another market, ${ }^{63}$ but that does not extend to effects upon society at large. Allowing non-competition social benefits to justify losses of consumer welfare obviously harms consumers; so, too, does using noncompetition social harms to deny benefits to consumers. Therefore, competition enforcers and courts must be careful to

59 European Commission Press Release IP/00/148, Commission Approves an Agreement to Improve Energy Efficiency of Washing Machines (Feb. 11, 2000), https://europa.eu/rapid/press-release_IP-00148_en.htm?locale=en [https://perma.cc/7J4H-J6Z9].

60 Commission Decision 2000/475, 2000 O.J. (L 187) 5.

61 Id. at 5 (discussing recoupment in nine to forty months).

62 Id. at 6.

63 But see United States v. Phila. Nat'l Bank, 374 U.S. 321, 370 (1963) (holding "anticompetitive effects in one market" cannot be justified by "procompetitive consequences in another"); U.S. DEP'T. OF JUSTICE \& FED. Trade Comm’n, Horizontal Merger Guidelines $§ 10$ (2010) ("Agencies consider whether cognizable efficiencies likely would be sufficient to reverse the merger's potential to harm customers in the relevant market . ...”). 
distinguish between qualitative effects that affect consumer welfare, on the one hand, and on the other, broader public interest considerations that affect consumers and nonconsumers alike.

This has long been the practice in all but a few jurisdictions. As Assistant Attorney General Makan Delrahim recently stated in connection with the Antitrust Division's investigation of an agreement among four automobile manufacturers and the State of California concerning emissions standards: "The loftiest of purported motivations do not excuse anti-competitive collusion among rivals." ${ }^{4}$ That, however, does not mean antitrust analysis should focus exclusively upon measurable price effects. To the contrary, antitrust analysis should incorporate qualitative effects to the extent that is practical, and the tools discussed below can aid antitrust practitioners, agencies, and courts in doing so.

\section{ADMINISTRATIVE AGENCY RULEMAKING CAN INFORM THE BALANCING OF UNQUANTIFIED HARMS OR BENEFITS}

Ever since President Ronald Reagan required executive branch agencies to do formal cost-benefit analyses before issuing significant regulations, ${ }^{65}$ federal agencies have been confronted with the task of accounting for costs and benefits that are difficult to quantify, ${ }^{66}$ such as changes (up or down)

64 Makan Delrahim, DOJ Antitrust Division: Popular Ends Should Not Justify Anti-Competitive Collusion, USA TODAY (Sept. 12, 2019), https://www.usatoday.com/story/opinion/2019/09/12/doj-antitrust-divisionpopular-ends-dont-justify-collusion-editorials-debates/2306078001/ [https://perma.cc/C7HA-AAA5].

65 Exec. Order No. 12,291, Federal Regulation, 3 C.F.R. 127 (1982). Some regulatory impact analysis is also required by the National Environmental Policy Act Pub. L. No. 91-190, 83 Stat. 852, 852 (1970), the Regulatory Flexibility Act Pub. L. No. 96-354, 94 Stat. 1164, 1164 (1980), the Unfunded Mandates Reform Act of 1995 Pub. L. No. 104-4, 109 Stat. 48, 50, and the Paperwork Reduction Act of 1980 Pub. L. No. 96-511, 94 Stat. $2812,2825$.

66 Eric A. Posner \& Cass R. Sunstein, Moral Commitments in CostBenefit Analysis, 103 VA. L. REV. 1809, 1819-23 (2017); see also Cass R. 
in environmental pollution, or are inherently unquantifiable, such as effects on human dignity. ${ }^{67}$ Agencies' need for analytical tools to deal with these challenges has elicited from academic and other sources a number of increasingly sophisticated methods for quantifying previously unquantified effects, such as incremental improvements in human health and the environment, and for taking account of unquantifiable but undeniably relevant considerations. ${ }^{68}$ As regulations written by the agencies have been challenged in court, the judiciary in turn has been called upon to review

Sunstein, The Limits of Quantification, 102 CALIF. L. REV. 1369, 1369-70 (2014).

67 See Office of Mgmt. \& Budget, Exec. Office of the President, OMB Circular A-4, at 26-27 (2003); see e.g., Nondiscrimination on the Basis of Disability in State and Local Government Services, 75 Fed. Reg. 56,164, 56,169 (Sept. 15, 2010) (codified at 28 C.F.R. pt. 35).

68 See e.g., U.S. DeP'T of Transp., OfFice of the SEC'Y, Benefit-Cost Analysis Guidance for Discretionary Grant Programs 5-6 (2018), https://www.transportation.gov/sites/dot.gov/files/docs/mission/officepolicy/transportation-policy/14091/benefit-cost-analysis-guidance-2018.pdf [https://perma.cc/66GE-MWEL]; Envtl. Prot. Agency Office of Policy, Guidelines FOR PREPARING ECONOMIC ANALYSES (2014), https://www.epa.gov/sites/production/files/2017-08/documents/ee-0568-

50.pdf [https://perma.cc/JB5S-A8Q9]. See also JEFFREY S. LUBBERS, A GUIDE to Federal Agency Rulemaking 255-59 (6th ed., 2018) (discussing the evolution of requirements for regulatory analysis, including best practices recommended for agencies by the Office of Management and Budget under the Bush and Obama Administrations); OfFice of MGMT. \& Budget, OfFice OF INFO. AND REGULATORY AFFAIRS, 2017 DRAFt REPORT TO CONGRESS ON THE Benefits and Costs of Federal Regulations and Agency Compliance With THE Unfunded MANDATES REForm ACT (2017), https://www.whitehouse.gov/wpcontent/uploads/2017/12/draft_2017_cost_benefit_report.pdf

[https://perma.cc/WE86-CZ3U]; Douglas A. Kysar, Politics by Other Meanings: A Comment on "Retaking Rationality Two Years Later" 48 Hous. L. REV. 43, 46-47 (2011) (analyzing "areas of improvement in the practice of cost-benefit analysis" while recognizing the limits of current tools available to estimate health and environmental effects of regulations); Cass R. Sunstein, The Limits of Quantification, 102 CALIF. L. REV. 1369, 1369 (2014) (recommending agencies engage in breakeven analysis when quantification is impossible). 
agencies' efforts. ${ }^{69}$ Executive and judicial review of agency rulemaking involving unquantified costs or benefits therefore provides useful illustrations that can help antitrust agencies and courts approach the problem of balancing incommensurable effects in antitrust cases.

\section{A. Executive Review}

To be sure, agency analyses of unquantified benefits is far from universal. Faced with costs and benefits of a proposed regulation that are difficult to quantify, some agencies do not make even a rudimentary effort to consider the likely effects of the regulation. ${ }^{70}$ Agencies that have made the effort to take account of unquantified costs and benefits have, however, built a set of tools to inform their analyses upon which the antitrust agencies and courts hearing antitrust cases can now draw. ${ }^{71}$

The current Executive Order laying out the process for regulatory review directs agencies to "include both quantifiable measures (to the fullest extent that these can be usefully estimated) and qualitative measures of costs and benefits that are difficult to quantify, but nevertheless

69 See infra notes 82-91 and accompanying text. See also Caroline Cecot \& W. Kip Viscusi, Judicial Review of Agency Benefit-Cost Analysis, 22 Geo. MAson L. REV. 575 (2015).

70 See e.g., Jonathan S. Masur \& Eric A. Posner, Unquantified Benefits and the Problem of Regulation under Uncertainty, 102 CORNELL L. REV. 87, 104 (2016) (estimating more than $74 \%$ of regulations analyzed by the authors included relevant costs or benefits the agency could not quantify); Eric A. Posner \& Cass R. Sunstein, Moral Commitments in Cost-Benefit Analysis, 103 VA. L. REV. 1809, 1858-59 (2017) ("Sometimes, however, regulations are designed to protect third parties or otherwise to promote moral values, and agencies have struggled to quantify their benefits; often they ignore them.”); CuRTis W. COPELAND, ECONOMIC ANALYSIS AND INDEPENDENT REGULATORY AGENCIES 4 (2013), https://www.acus.gov/sites/default/files/documents/Copeland\%20Final\%20 BCA\%20Report\%204-30-13.pdf [https://perma.cc/2P8Q-TBGE].

71 Michael A. Livermore, Cost-Benefit Analysis and Agency Independence, 81 U. CHI. L. REV. 609, 640-41 (2014) (describing an iterative process between agencies and the Office of Information and Regulatory Affairs to develop guidelines for cost-benefit analysis). 
essential to consider." ${ }^{2}$ The Office of Information and Regulatory Affairs ("OIRA") in the Office of Management and Budget (the "OMB"), which runs the regulatory review process, directs agencies to take unquantified costs and benefits into account by "present[ing] any relevant quantitative information along with a description of the unquantified effects, such as ecological gains, improvements in quality of life, and aesthetic beauty."73 Including similar information about qualitative effects of a business practice or a merger could improve the ability of antitrust practitionersand consequently, antitrust agencies and courts-to account for qualitative benefits in their analysis.

Agencies have invested in the quantification of benefits that are difficult to monetize, such as the value of a human life. ${ }^{74}$ The Environmental Protection Agency (the "EPA") has based its valuation of a statistical life upon studies of individuals' revealed preferences, such as the additional wages people demand to take up riskier occupations. ${ }^{75}$ The EPA has used this value of a statistical life in cost-benefit analyses of environmental regulations, such as the value of

72 Exec. Order No. 12,866, Regulatory Planning and Review, 3 C.F.R. 638 (1993) (amended and modified but not withdrawn by Exec. Order No. 13,563, Improving Regulation and Regulatory Review, 3 C.F.R. 215 (2012) and Exec. Order No. 13,771, Reducing Regulation and Controlling Regulatory Costs, 82 Fed. Reg. 9340 (Jan. 30, 2017)).

73 Office of Mgmt. \& Budget, Exec. Office of the President, omB Circular A-4, at 27 (2003).

74 See e.g., Envtl. Prot. Agency OfFice of Policy, supra note 68 at 113. See also W. Kip Viscusi and Joseph E. Aldy, The Value of a Statistical Life: A Critical Review of Market Estimates Throughout the World, $27 \mathrm{~J}$. RISK AND UnCERTAINTY 5 (2003); W. Kip Viscusi, The Value of Life: Estimates with Risks by Occupation and Industry, 42 ECON. INQUIRY 29 (2004).

75 See Envtl. Prot. Agency Office of Policy, supra note 68. See also Richard L. Revesz, Quantifying Regulatory Benefits, 102 CALIF. L. REv. 1423, 1436-37 (discussing methodologies supporting valuations of a statistical life used by the EPA and Department of Transportation in costbenefit analysis). 
deaths avoided by reducing particulate emissions under the Clean Air Act. ${ }^{76}$

To ensure agencies take into account as many unquantified costs and benefits as possible, the OMB recommends that agencies use a "break-even analysis" to aid their decisionmaking. ${ }^{77}$ For example, the Civil Rights Division of the DoJ used a break-even analysis to resolve a difficult comparison of costs and benefits in its analysis of new standards requiring increased space in restrooms to facilitate access for people in wheelchairs. ${ }^{78}$ The agency recognized the quantified costs outweighed the quantified benefits of the rule, but concluded that the unquantifiable benefits of "enhanced independence, and the avoidance of stigma and humiliation" would be "quite high."" But that was not an unsupported statement. The break-even analysis had shown that costs in excess of quantified benefits would be "under 5 cents per visit." 00 The DoJ reasoned, "based on its experience and informed judgment, that 5 cents substantially understates the value people with the relevant disabilities would place on these benefits." ${ }^{1}$ The DoJ performed a similar break-even analysis in its regulation implementing the Prison Rape Elimination Act. ${ }^{82}$ The National Highway Traffic Safety

76 Federal Implementation Plans: Interstate Transport of Fine Particulate Matter and Ozone and Correction of SIP Approvals 76 Fed. Reg. 48,208, 48,311-15 (Aug. 8, 2011) (codified at 40 C.F.R. pts. 51, 52, 72, 78, 97).

77 Office of Mgmt. \& Budget, supra note 73, at 2.

78 Nondiscrimination on the Basis of Disability in State and Local Government Services, 75 Fed. Reg. 56,164, 56,169 (Sept. 15, 2010) (codified at 28 C.F.R. pt. 35).

79 Id. at 56,170 .

$80 I d$. (estimating per visit costs based upon the yearly amount of excess costs divided by the estimated number of yearly restroom visits by people with disabilities who would benefit from the rule).

81 Id.

82 The DoJ first estimated the benefits of preventing sexual assault at $\$ 310,000$ to $\$ 480,000$, reflecting the tangible losses (medical expenses and lost wages) as well as intangible losses (pain, suffering, and reduced quality of life) valued on the basis of jury awards to compensate crime victims for pain and suffering. It then calculated that only 1,671 sexual assaults (or less than $1 \%$ of the annual sexual assaults in prisons) would have to be 
Administration ("NHTSA") also used break-even analysis to evaluate the potential benefits of a rule mandating back up cameras in cars insofar as they would save parents from running over and killing their own children. ${ }^{83}$

\section{B. Judicial Review}

Courts have upheld agency regulations that were based in part upon consideration of unquantified costs or benefits. They have also, however, placed limits upon agencies' ability to evade a rigorous cost-benefit analysis by using unquantified harms or benefits to justify new regulations. Administrative law cases can not only help guide antitrust practitioners looking to incorporate regulatory quantification tools into their arguments; they can also help courts evaluate those arguments when considering unquantified effects in antitrust cases.

A court considering a regulation the issuing agency justified in whole or in part by invoking unquantified benefits may look into the basis for the agency's claim that the benefit has substantial value and consider the difficulty involved in quantifying it. In FCC v. Fox Television Stations, Inc., the Supreme Court upheld a regulation based entirely upon a qualitative benefit, the protection of children from indecent speech, against the claim the regulation was arbitrary and capricious because the agency had failed to quantify the potential benefits of preventing children's exposure to

prevented in order for the benefits of the regulation to fully offset its costs. National Standards to Prevent, Detect, and Respond to Prison Rape, 77 Fed. Reg. 37,106, 37,110-11, 37,188-89 (June 20, 2012) (codified at 28 C.F.R. pt. 115).

83 NHTSA estimated the cost of each death that would be prevented by the rule, between $\$ 11.8$ and $\$ 19.7$ million, exceeded the value of a statistical life usually used by the agency. NHTSA's analysis suggested that if preventing tragic accidents in which parents ran over their own children was worth $\$ 65$ to $\$ 79$ per vehicle then the costs of the regulation would be justified. Federal Motor Vehicle Safety Standard, Rearview Mirrors; Federal Motor Vehicle Safety Standard, Low-Speed Vehicles Phase-In Reporting Requirements, 75 Fed. Reg. 76,186, 76,238 (Dec. 7, 2010) (codified at 49 C.F.R. pts. 571, 585). 
"fleeting expletives." ${ }^{4}$ The Court explained that, while it would not hesitate to "set aside agency action under the Administrative Procedure Act because of failure to adduce empirical data that can readily be obtained[,]" it would not fault the FCC for failing to "obtain[ the unobtainable." 85 Requiring the FCC to quantify that harm in order to protect children would make "a nullity" of the statute charging the FCC with that task. ${ }^{86}$ The Court also noted that it had previously held a regulation of otherwise protected expression was justified by the "government's interest in the well-being of its youth[,]" despite having "no quantifiable measure of the harm caused by the [indecent] language." 87

In contrast, some courts have held agencies to account for failing to quantify costs or benefits when the agency could have done more. ${ }^{88}$ Perhaps one of the best-known examples is Corrosion Proof Fittings $v$. EPA. ${ }^{89}$ In that case, the Fifth Circuit vacated an EPA regulation banning several asbestos

84 FCC v. Fox Television Stations, Inc., 556 U.S. 502, 519-20 (2009).

85 Id. at 519 (citation omitted).

86 Id.

87 Id. at 519-520 (citing FCC v. Pacifica Found., 438 U.S. 726, 749-50 (1978)). See also Nat'l Ass'n of Mfrs. v. SEC, 748 F.3d 359, 369 (D.C. Cir. 2014) (likening the balancing of monetary costs against the unquantifiable benefits of increasing transparency relating to conflict minerals to an "apples-to-bricks comparison"), rev'd on other grounds, 760 F.3d 18 (D.C. Cir. 2014); Am. Meat Inst. v. USDA, 760 F.3d 18 (D.C. Cir. 2014).

88 In addition, one court chastised the Department of the Interior for failing to take into account qualitative benefits, such as the value people derive from protecting a natural resource, such as a lake or mountain. Ohio v. U.S. Dep't. of Interior, 880 F.2d 432, 438, 462-63 (D.C. Cir. 1989) (vacating in part the Department of Interior rule implementing the Compensation and Liability Act of 1980 because it failed to account for the existence and option values of natural resources in its hierarchy of methodologies to estimate the value of damaged natural resources). But see Denis Swords, Ohio $v$. United States Department of the Interior: A Contingent Step Forward For Environmentalists, 51 LA. L. REV. 1347, 1367-70 (1991) (arguing the D.C. Circuit misinterpreted CERCLA when determining that non-use values, such as the existence of a natural resource, must be taken into account when evaluating environmental damages).

89 Corrosion Proof Fittings v. EPA, 947 F.2d 1201 (5th Cir. 1991). 
products in part because the EPA had relied upon but failed to quantify the benefits of the regulation; the EPA justified the costs of banning additional asbestos products that were not fully offset by the quantified benefits of the regulation by relying upon the unquantified value of those lives potentially saved by the regulation more than thirteen years in the future. The court recognized "[u]nquantified benefits can, at times, permissibly tip the balance in close cases" but they "cannot ... be used to effect a wholesale shift on the balance beam." failure to support its conclusion with substantial evidence and to consider less burdensome alternatives, as required by the Toxic Substances Control Act.

Courts have also vacated regulations based upon an agency's failure to quantify costs. In Chamber of Commerce $v$. $S E C$, although the D.C. Circuit agreed with the SEC's decision not to do an empirical study of the benefits of increasing the minimum percentage of independent members on the boards of mutual funds, it vacated the regulation based upon the SEC's failure even to study the costs it was imposing. ${ }^{91}$ "[U]ncertainty may limit what the Commission can do, but it does not excuse the Commission from its statutory obligation to do what it can to apprise itself-and hence the public and the Congress - of the economic consequences of a proposed regulation before it decides whether to adopt the measure."92 In the same vein, in Business Roundtable v. SEC, the D.C. Circuit vacated another SEC rule because the agency, among other flaws, had "failed adequately to quantify the certain costs or to explain why those costs could not be quantified."93

These judicial admonitions to quantify costs and benefits where possible, or where directed by statute to do so, resemble the best practices laid out by the Office of Management and Budget in its Circular A-4 directing agencies to quantify what they can in a cost-benefit analysis in order to aid in OIRA's

\footnotetext{
90 Id. at 1219.

91 Chamber of Commerce v. SEC, 412 F.3d 133, 136 (D.C. Cir. 2005).

92 Id. at 144.

93 Bus. Roundtable v. SEC, 647 F.3d 1144, 1148-49 (D.C. Cir. 2011).
} 
evaluation of the rule. Surely the antitrust agencies, each of which has several dozen Ph.D. economists on its staff, can be expected to do as well as other agencies in quantifying the likely effects of a merger or practice subject to the rule of reason. Of course, there will be some effects that simply defy quantification, even in the form of a rough estimate, but it is important to minimize the number of harms and benefits that are not accounted for in the analysis.

\section{PROPOSAL TO HELP INFORM BALANCING OF UNQUANTIFIED HARMS AND BENEFITS}

Let me connect this discussion back to the goals of antitrust that motivated President Taft in his day and continue to drive enforcement of the Sherman Act in ours. Meeting the challenge of balancing qualitative harms or benefits in an antitrust case is not a reason to depart from the consumer welfare standard. On the contrary, this balancing exercise requires an evidence-based approach to incorporating into the consumer welfare standard those qualitative effectsboth anticompetitive harms and procompetitive benefits-of a restraint of trade.

Inherent in this task is the requirement for a party or an agency that relies upon a qualitative harm or benefit to quantify those effects that can be quantified and to provide evidence to substantiate the value of the potential harm or benefit. For a claimed competitive harm or benefit that remains unquantified, the decisionmaker should demand both a convincing showing that the magnitude of the effect cannot be quantified and a sound theoretical basis for nonetheless believing the effect will be real and substantial.

The regulatory toolkit could be useful, for example, when an antitrust agency is evaluating a claim that a merger will benefit innovation. The agency might demand from the parties evidence regarding the probability of increased innovation, examples of similar mergers realizing similar efficiencies, and proof of the parties' incentive to pass on savings to consumers.

In cases where an agency is making a prediction about the harm to innovation owing to a restraint or a proposed merger, 
these tools could increase the transparency and rigor of its analysis. For example, in the consent decree approving the Roche-Genentech merger, the FTC required relief in markets where it would be several years until the products the companies were developing could compete. Discounting the potential harm by the likelihood that, but for the merger, both these products would eventually come to market would more precisely estimate the potential harms of the merger. Additional information about the availability of other, similar drugs either in the market or under development by other companies could also provide helpful guidance about the potential harm to consumers. Ultimately, including this information could not only improve the agency's own analysis, but also provide guidance to companies working to evaluate antitrust risk in future transactions.

Break-even analysis and valuations of morbidity or mortality could also be used in hospital merger cases, for example, by balancing harms quantified by the agency with benefits quantified by the defendants. The defendants in the Saint Alphonsus Medical Center-Nampa Inc. v. St. Luke's Health System, Ltd. hospital merger case tried to rebut the FTC's allegation that the merger would increase prices by arguing generally that the merger would also increase quality. ${ }^{94}$ St. Luke's itself estimated the increase in prices would cost consumers an additional $\$ 1.65$ million per year. ${ }^{95}$ A break-even analysis would look to qualitative benefits, such as the claimed improvement in the quality of primary care. If the defendants could show the improvement would save even one additional life per year, the defendants could use the value of a statistical life (about $\$ 10$ million) to show the benefits of the merger to some patients would dwarf the costs of the

94 Saint Alphonsus Med. Ctr.-Nampa Inc. v. St. Luke's Health Sys., Ltd., 778 F.3d 775, 791 (9th Cir. 2015).

95 Saint Alphonsus Med. Ctr.-Nampa, Inc. v. St. Luke's Health Sys., Ltd., Nos. 1:12-CV-00560-BLW, 1:13-CV-00116-BLW, 2014 WL 407446, at *12 (D. Idaho Jan. 24, 2014) ('St. Luke's own analysis projected that it could gain an extra $\$ 750,000$ through hospital-based billing from Saltzer from commercial payers for lab work and $\$ 900,000$ extra for diagnostic imaging."), aff'd 778 F.3d 775 (9th Cir. 2015). 
merger to others; ${ }^{96}$ there would be an increase, not a decrease, in consumer welfare if the merger were approved.

Some cases, including some cases discussed above, ask courts and agencies to balance qualitative benefits or harms that are not just difficult to quantify, they are inherently unquantifiable. In balancing qualitative effects, it is important to recognize the limitations of any attempt to measure or even estimate the value of the harm or benefit. For example, in adopting regulations concerning prison rape and restroom facilities, respectively, the DoJ was able to take into account the constitutional rights of prisoners and the dignity of persons in wheelchairs by doing a break-even analysis even though those values are inherently unquantifiable. ${ }^{97}$

Across these different efforts to account for qualitative harms and benefits the standard of evaluation should remain consumer welfare. Evaluating the qualitative costs and benefits is not an invitation to look beyond the effects on consumers and to incorporate the effects on the public at large. As practitioners consider using these tools to better account for qualitative effects in antitrust investigations and trials, they must be careful to focus upon consumer welfare as the lodestar guiding their efforts; the antitrust agencies will properly disregard claims that a business practice or a merger will benefit the general public. Further quantification is a step toward a more precise accounting under, not a departure from, the consumer welfare standard.

Agencies can take that step forward by quantifying aspects of hard-to-measure harms when bringing a complaint; for example, when assessing harms to innovation an agency might do a more rigorous analysis of the likelihood that

96 This example uses an approximate valuation of a statistical life for illustrative purposes. See W. Kip Viscusi, The VSL Is Not Too High, REG., Winter 2018-2019, at 2, available at https://www.cato.org/sites/cato.org/files/serials/files/regulation/2018/12/reg ulation-v41n4-7.pdf [https://perma.cc/FDM8-Q89T].

97 National Standards to Prevent, Detect, and Respond to Prison Rape, 77 Fed. Reg. 37106, 37,110-11, 37,188-89 (June 20, 2012) (codified at 28 C.F.R. pt. 115); Nondiscrimination on the Basis of Disability in State and Local Government Services, 75 Fed. Reg. 56,164, 56,169 (Sept. 15, 2010) (codified at 28 C.F.R. pt. 35). 
research will be successful in developing a product. A party defending a restraint can take that step forward by quantifying the value of an improvement in quality or service it claims in justification. Lastly, courts can help all parties take these steps forward by embracing the use in antitrust cases of tools developed for regulatory cost-benefit analysis. 